\title{
IMPACT OF AGRICULTURAL SERVICES PROVIDED BY NON-STATE ACTORS ON RURAL LIVELIHOODS: A CASE OF DISTRICT MANSEHRA, KHYBER PUKHTUNKHWA, PAKISTAN
}

\author{
Muhammad Luqman ${ }^{1, *}$, Babar Shahbaz ${ }^{2}$ and Tanvir Ali ${ }^{2}$ \\ ${ }^{1}$ University College of Agriculture, University of Sargodha, Pakistan \\ ${ }^{2}$ Agricultural Information Institute of CAAS, Beijing 100081, China \\ ${ }^{3}$ Institute of Agri. Ext. \& Rural Development, University of Agriculture, Faisalabad, Pakistan \\ *Corresponding author's e-mail: extensionpak@gmail.com
}

The failure of state actors/institutions in the country in delivering agricultural advisory and extension services to the rural community created a space for non-state actors to deliver these services at the door steps of majority of the rural poor people in order to improve their livelihoods. This situation prevails in all the four provinces of the country especially in Khyber Pakhtunkhwa province, where rural poverty is evident. In order to access the impact of agricultural services rendered by different non-state institutions on the livelihoods of rural poor in this region, the current research study was designed. The study was conducted in district Mansehra (one of the most populated district of Hazara division). Both qualitative and quantitative approaches were used for the collection of data from respondents. The data were collected from the rural community of those villages where the selected non-state organizations were involved in a variety of rural development related activities/tasks. The data were collected from 450 respondents randomly selected from 6 villages. The collected data were analyzed by using computer based statistical software - SPSS. From the results it was concluded that majority of the respondents had age between 36-50 years with secondary educational level. The land holding size of the respondents in the research was very small. It was also concluded that a large majority (>80.0\%) of respondents said that agricultural services rendered by non-state institutions like extension education, trainings related to crop \& livestock management, poultry \& forestry services, vaccination for livestock and awareness campaigns regarding latest agricultural technologies improved their overall agricultural productivity as well as livelihoods. It was also concluded that regarding impacts of agricultural services rendered by non-state organizations, a large majority of the respondents $(89.6 \%)$ said that their agricultural services increased their agricultural productivity. While exploring the reasons due to which agricultural related services of non-state organizations play role in improving livelihoods of rural people, the results of the study indicated that in extension and education services majority $(54.6 \%)$ of the respondents said that social organizations provided good quality extension and education related services to the rural community. Finally, it was concluded that agricultural services of non-state organizations were very effective and played a significant role in upgrading the livelihoods of rural poor.

Keywords: Agricultural services, non-state actors, agricultural extension, rural livelihoods

\section{INTRODUCTION}

The importance of agriculture in the inclusive economic development of a country is well recognized due to its significance in poverty reduction and ensuring food security (Cervantes and Dewbre 2010). It has direct positive impact on the economy of rural households (DFID, 2004). Moreover, the role of agriculture is inevitable to feed an ever growing population of about 9 Billion up to 2050 (Muzari et al., 2012). Its significance is specifically very much crucial in developing countries like Pakistan, where a large number of rural people are facing the problems of poverty and food insecurity (FAO, 2012). The provision of agricultural advisory services to these poor and food insecure people is the pre-requisite for entire agricultural as well as rural development (ibid).
In the entire world providing agricultural advisory services to the farmers is the most common exercise being practiced at national and provincial level (Cerdán-Infantes et al., 2008). Most commonly these services are referred to as rural advisory services (Nederlof et al., 2010). The basic function of these agricultural services is to educate rural people about latest farming techniques (Chipeta, 2006). For the provision of these services both state and non-state actors are working s (FAO, 2003). Specifically, with reference to developing countries Saliu et al. (2009) divided agricultural extension service providers into three different categories as public, private and non-profit sectors. In a broader sense, these institutions are divided into state and non-state agricultural extension service providers. But, generally in the whole world and specifically in developing and low income countries like Pakistan, the state-led agricultural extension service provider 
is confronted with a number of challenges in term of availability and effectiveness of agricultural advisory services (Ajieh et al., 2008).

Like other South Asian countries, same is the fate of agricultural services provided by state institutions in Pakistan in the form of public sector agricultural extension services (Ali et al., 2011). Similar to the other provinces of the country in Khyber Pakhtunkhwa province provincial level agricultural extension department is responsible for providing agricultural related services which include outreach/extension and education, trainings related to crops and livestock management, provision of improved seed, fertilizers and other farm inputs (Khan et.al., 2012). But the existing system is not catering and responsive to the actual needs of the rural poor being traditional and out dated (Farooq et al., 2010). Similar findings about the performance of agricultural extension in Khyber Pakhtunkhwa province was also reported by Haque (2002) while reporting the major institutional reforms in the current agriculture extension and advisory services to the farmers. Moreover, due to the high illiteracy level among farmers in the KP province minority of the farmers depend on stated owned agricultural extension and advisory services. But majority of the farmers have no or very least access to these services (UNDP, 2012).

This above said status of poor working efficiency of stated led agricultural institutions in the province created a gap in delivering agricultural advisory services to the rural poor at their door steps which is filed by different non-state institutions especially Non-governmental organizations (Luqman et al., 2013). These non-state institutions developed a modern and effective network of rural based farmer organizations and used a wide variety of extension methodologies to educate farmers through self-based learning (Khan, 2009). However, the actual performance and impacts of these non-state rural actors on livelihoods of rural people of district Mansehra of Khyber Pukhtunkhwa province is not yet been explored. With this major objective the present study was designed with specific objectives to explore the nature and role of non-state organizations in improving livelihoods of rural people, find out the impacts of agricultural advisory services rendered by non-state organizations in the study area and explore the statistical difference between satisfaction

${ }^{1}$ Executive District Officer (EDO), Social welfare, Special Education and Women Empowerment Department, District Peshawar and Mansehra, Chairman, Citizen Community Board Network, District Mansehra and Peshawar, Director Agriculture Extension, District Peshawar, Abbotabad and Mansehra, Chairman/chairpersons/heads of social welfare organizations, Local activists, Local religious as well as political leaders, Journalists/civil society activists, staff of Pakistan Academy for Rural Development, Peshawar, Chairman of farmer associations (Pakistan KisanItehad)

${ }^{2}$ In total ten (10) focus group meetings were conducted (1 for staff/volunteers of each selected three organizations, 1 for staff of state led agricultural level of respondents about the agricultural advisory services of different non-state organizations.

\section{MATERIALS AND METHODS}

The present study was conducted in Khyber Pukhtunkhwa province of Pakistan which was primarily known as North West Frontier Province (NWFP). The entire province is divided into 25 districts. Case study approach was adopted in this study which was limited to only one district due to financial and time constraints. Out of the total 25 districts, one district (Mansehra) was randomly selected as the study area. Both qualitative and quantitative approaches were used for the collection of data. Quantitative data were collected with the help of a reliable and validated structured interview schedule while qualitative data was collected through interview guide by conducting key informant interviews ${ }^{1}$ and focus group discussions ${ }^{2}$.

At the initial step inventory of non-state organizations which were involved in different agricultural related activities in the research area was prepared in consultation with the key informants. The same technique was also adopted by Botchwey (2006) while determining the role of social organizations in local community development. From that inventory of 16 total organizations, three organizations were randomly selected. The names of the selected three organizations were Al-Khidmat Foundation, Sungi Development Foundation and Rural Development Support Organization (RDSO). The data were collected from the rural community of those villages where the selected non-state organizations (as mentioned above). The lists of villages were prepared in consultation with the key informants. Two villages for each of the selected three organizations were randomly selected and making a total of 6 villages. From each of the six (06) selected villages 75 households ${ }^{3}$ were randomly selected. Face to face interviews were conducted from head of each household. The total sample size was 450 respondents. The collected data were analyzed by using computer based statistical software - SPSS. Descriptive as well as inferential statistics was used to describe the results. F-test ${ }^{4}$ was used to find out the statistical difference between the satisfaction level of respondents regarding provision of

extension department, 1 for rural residents of each of the selected 6 villages) The total number of participants in each focus group meeting was ten (10).

${ }^{3}$ A list was prepared for those households who were registered as member with the respective organization was prepared first and then from that list 75 households were randomly selected and head of each of the selected household were interviewed. That list include all the households who earn through both farm and non-farm income sources.

${ }^{4}$ F-test was used to find out the difference in opinion of respondents about the delivery of services by the respective organizations as the working strategies and operational/coverage area of all the three organizations is different 
different agricultural related services by the selected three non-state organizations working in the study area.

\section{RESULTS AND DISCUSSIONS}

\section{Demographic profile of respondents:}

Age: The total number of years of an individual from the day of his/her birth up till the day of data collection from the field. It has great influence on the social and mental behaviour of a people (Naeem, 2005). Keeping in view the importance of age in social science research studies among other socioeconomic factors, the data in this regard was collected in the present research study, which is tabulated in Table 1 and also discussed below:

Table 1. Distribution of the respondents according to their age.

\begin{tabular}{lcr}
\hline Age (in Years) & f & \% \\
\hline $18-35$ & 140 & 31.1 \\
$36-50$ & 183 & 40.7 \\
$51-70$ & 111 & 24.7 \\
$70+$ & 16 & 0.6 \\
Total & 450 & 100.0 \\
\hline
\end{tabular}

The data presented in Table 1 regarding age of the respondents showed that majority (40.75) of the respondents had age between 36-50 years in the study area. And only few respondents $(3.6 \%)$ had age more than 70 years. To some extent similar results were also reported by Jalal-Ud-Din (2011) who said that majority $(41.42 \%)$ of the respondents was belonged to old age group having age between 46-55 years.

Educational level: The educational level is the yardstick to measure the status of a society. It is considered as a powerful source of change and development at individual as well as societal level (Siddiqui, 2006). In view of its importance in the present study the respondents were asked question about their formal educational level, and the data in this regard is presented in Table 4.2.

Table 2. Distribution of the respondents according to their educational status.

\begin{tabular}{lrr}
\hline Educational status & f & \% \\
\hline Illiterate & 56 & 12.4 \\
Primary & 105 & 23.3 \\
Middle & 110 & 24.4 \\
Secondary & 114 & 25.3 \\
Intermediate & 32 & 7.1 \\
Bachelor and Above & 29 & 6.4 \\
Vocational & 4 & 0.9 \\
Total & 450 & 100.0 \\
\hline
\end{tabular}

The data presented in Table 6.3 showed that majority of the respondents $(73.0 \%)$ has education up to secondary level and
$12.4 \%$ of the respondents were illiterate. To some extent similar results were also reported by Khan et al. (2009) and Jalal-Ud-Din (2011). In the present research study only $0.9 \%$ of them had vocational education and training and only $6.4 \%$ of the respondents had graduation or higher level education in the research area. In the stud area low education and lack of technical and vocational trainings to the community was one of the causes of ever increasing poverty. During qualitative focus group discussion meetings people emphasized that "poverty and inequality can only be reduced through education and training". The respondents further emphasized that low educational level of the farming community in the study area and in the whole province also contributes in low agricultural output in terms of production and alarming poverty and food insecurity situation.

Size of land holding: Size of land holding is the ownership of agricultural land which is in the possession of an individual himself or by his/her family. It is an important factor in taking decisions regarding agricultural (crop and livestock practices) (USDA, 2007). In rural areas of Pakistan land is the principal asset and is the main source income. In the present research study it was found that slightly more than $60.0 \%$ of the respondents had agricultural land. This situation also bound the rural community to earn money from non-agricultural resources/non-farm in order to secure their livelihoods. The data concerning land holding of the respondents is given in Table 3 .

Table 3. Household's size of land holding.

\begin{tabular}{lc}
\hline Land holding & Size (in Kanals) \\
\hline Minimum & 1.5 \\
Maximum & 310 \\
Average & 43.65 \\
\hline
\end{tabular}

The data concerning size of landholding in the research area as presented in table 3 reveals that the land holding of the people is very small. The minimum size of land holding in the area was 1.5 kanals and maximum size was 310 kanals. The average land holding size in the study area was 43.65 kanals. This minimum size of land holding in the area bound the rural people to do subsistence farming. Majority of the households didn't even grow cereal crops for annual food consumption for their own family. This indicates the status of food security in the area. The results of the present study are also similar to that of the Pervaiz et al. (2013). During qualitative key informant interviews one of the informants said that:

"we have very small agricultural land and major portion of this land is uneven, we need a lot of financial capital to level the land and to make it useful for cultivation but we have least financial resources and financial capital so we rely on other sources of income like labour and driving"

The qualitative remarks captioned above confirmed that small farmers with small size of land holding have less income and substandard farming. This situation makes the farmer poorer 
and poorer. It was also observed that in the research area the households who had small or no land (agricultural labourer) were poorer than others and were facing high level of food insecurity. This proved that small farmers and farm labourere who have no land are the highly food insecure people as they have no alternate income sources. Due to the high food insecurity level among these rural communities the livelihoods of these people are under heavy pressure.

Nature of agricultural service providers: In the present research respondents were asked questions regarding the nature of agricultural related service providers. They were asked to tell from whom they receive agricultural services i.e. from state institutions or non-state institutions, and the data in this regard is tabled in Table 4.

The data presented in Table 4 showed that a large majority $(>70.0 \%)$ of the respondents reported that agricultural services like extension education, trainings related to crop/fruits/vegetable production as well as livestock production \& management were mainly provided by non-state actors (social organizations) in comparison to the state/government departments. In providing different agricultural related services, high majority of the respondents argued that state departments seldom involved in delivering agricultural and extension related services to the community. Among variety of agricultural services rendered by state institutions for rural farming community only minor percentage $(14.4 \%)$ of the respondents said that they receive forestry services as well as vaccination for livestock from state owned agricultural related departments/institutions. This percentage is highest among other agricultural services delivered by state departments/institutions at the door steps of farmers who are more vulnerable to poverty and food insecurity.

These findings are in accordance with the findings of Ahmed et al. (2009) who concluded that civil society organizations (non-state institutions) had an edge over public sector agriculture extension in delivering agricultural services to the people. The findings of quantitative data confirms the findings of qualitative data as during focus groups meetings a number of respondents reported that extension department of the district is inefficient and didn't perform their duties well. Regarding performance of non-state rural organizations in upgrading livelihoods of rural poor and poor efficiency of state departments it was noted during qualitative discussion that personals of state agriculture related departments rarely contact with the rural people as one of the person in the village Khairabad (UC Kurnool) said that

"in our village no official of the agriculture department came to update our knowledge regarding rural livelihood farming strategies. So we contact with the organizations for our agriculture related problems. In most of the cases the personnel of agriculture department only visit the field of influential persons of the area"

The above captioned qualitative remarks confirmed the inefficiency of the state extension department and efficiency of non-state rural institutions (network of social organizations) in delivering up-to-date agricultural services at their door steps. Many of the respondents reported that they didn't receive agricultural related services both from state and non-state institutions. They argued that their forefathers used to do farming since many years. There is no need to consult any person about what to grow and how to grow?

Opinion of respondents about impact of agricultural services of non-state organizations on rural livelihoods: Agricultural services provided to rural poor plays an important role in escaping them from poverty and improving livelihoods by increasing agricultural production (McCulloch et al., 2007). In order to prove this fact with special reference to KP province Pakistan (research area), the respondents were asked question about the impact of agricultural services on the livelihoods of rural people and also overall productivity of their farm. The data in this regard is presented in Table 5.

The data tabulated in Table 5 indicate that trainings related to crops/fruits or vegetable production imparted by non-state institutions (organizations) improved their agricultural productivity as well as their livelihoods as reported by an overwhelming majority $(95.5 \%)$ of respondents who received agricultural related services from different non-state

Table 4. Percentage distribution of the respondents from whom they receive different agricultural related services.

\begin{tabular}{|c|c|c|c|c|c|c|}
\hline \multirow[t]{2}{*}{ Agricultural Services } & \multicolumn{2}{|c|}{ State Actors } & \multicolumn{2}{|c|}{ Non-State Actors } & \multicolumn{2}{|c|}{ Non-recipient of Agri. services } \\
\hline & f & $\%$ & f & $\%$ & $\mathbf{f}$ & $\%$ \\
\hline Extension education & 43 & 9.6 & 324 & 72.0 & 83 & 18.4 \\
\hline $\begin{array}{l}\text { Trainings related to crops/fruits and } \\
\text { vegetable production }\end{array}$ & 14 & 3.1 & 348 & 77.3 & 88 & 19.6 \\
\hline $\begin{array}{l}\text { Trainings related to livestock } \\
\text { production and management }\end{array}$ & 17 & 3.8 & 381 & 84.7 & 52 & 11.6 \\
\hline Poultry & 10 & 2.2 & 247 & 54.9 & 193 & 42.9 \\
\hline Forestry services & 65 & 14.4 & 181 & 40.2 & 204 & 45.3 \\
\hline Vaccination for livestock & 65 & 14.4 & 203 & 45.1 & 182 & 40.4 \\
\hline $\begin{array}{l}\text { Awareness campaigns regarding } \\
\text { latest agricultural technologies }\end{array}$ & 33 & 7.3 & 225 & 50.0 & 192 & 42.7 \\
\hline
\end{tabular}


Table 5. Percentage distribution of the respondents according to their opinion about whether agricultural services of social organizations improve overall agricultural productivity and livelihood.

\begin{tabular}{lcccr}
\hline Agricultural Services & \multicolumn{2}{c}{ Yes } & No \\
\cline { 2 - 5 } & f & \% & f \\
\hline Extension education & 287 & 88.6 & 37 & 11.4 \\
Trainings related to crops/fruits and vegetable production & 332 & 95.5 & 16 & 4.6 \\
Trainings related to livestock production and management & 328 & 86.1 & 53 & 13.9 \\
Poultry management & 216 & 87.4 & 31 & 12.6 \\
Forestry services & 151 & 83.4 & 30 & 16.6 \\
Vaccination for livestock & 174 & 85.7 & 29 & 14.3 \\
Awareness campaigns regarding latest agri. technologies & 195 & 86.7 & 30 & 13.3 \\
\hline
\end{tabular}

organizations. Similar trend was also found in other agricultural services like extension \& education, trainings related to livestock production \& management, poultry management, forestry services, vaccination of livestock and awareness campaigns regarding latest agricultural technologies where a large majority $(>80.0 \%)$ of the respondents reported that agricultural services provided by non-state organizations play a significant role in improving their agricultural productivity. During focus group discussion, respondents said trainings related to crop and livestock management has numerous impacts on our livelihoods. After getting training which is mostly impacted by non-state organizations in the area, we become aware to latest crop and livestock management techniques. This helps us in increasing our farm income. This showed that all the agricultural services provided by non-state organizations in the study area played a significant role in bringing improvements in the overall livelihoods of the rural community as reported by a vast majority $(>80.0 \%)$ of the respondents. Regarding impacts of agricultural services delivered by local social organizations in the study area Shah et al., (2013) concluded that grassroots community organizations play an important role in enhancing food security and reducing poverty in rural areas of Haripur district of Hazara region (KPK province).

Impacts of agricultural services of non-state organizations: The respondents were asked question to find out the impact of agricultural services provided by non-state organizations on the rural livelihoods. The results showed that $100 \%$ of the respondents who received agricultural services from different non-organizations working in the study area reported the positive impacts of agricultural related services of non-state organizations. The respondents were further asked to describe those positive impacts and the data in this regard is given in Figure 1.

The data presented in Figure 1 clearly indicate that a large majority of the respondents $(89.6 \%)$ said that "increase crop productivity" is one of the leading impacts of agricultural services of non-state organizations working in the research area. The other impacts of these services were enhance food security situation, improve capacity building of farmers, enhance livelihood status, economic empowerment, enhance social capital status of farmers and natural resource conservation as reported by $89.5,89.1,88.1,86.2,85.0$ and $84.7 \%$, respectively. With regard to the results of present study Ahmad et al. (2009) also reported the positive impacts of agricultural efforts done by non-governmental organizations in Khyber Pukhtunkhwa province by building self-reliance capacity of local rural people. Further they also concluded that non-state organizations play an active role in upgrading the rural farming community as compared to the state departments. The impacts of civil society organization's farm related efforts on the livelihoods of rural poor were also described by Ghaus-Pasha (2004).

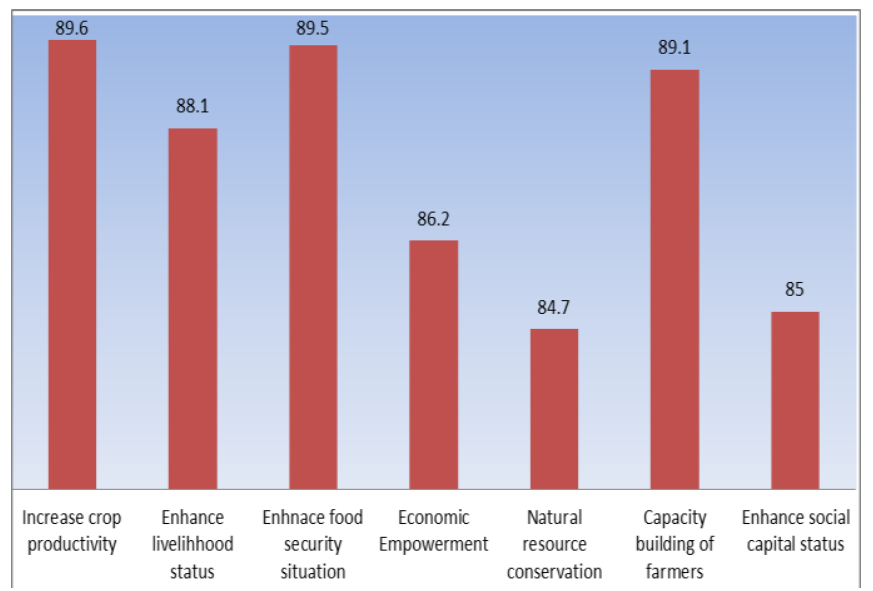

Figure 1.

Reasons behind improvement capability of agricultural services of local organizations: It has been proved through various research studies that agriculture plays an important role in improving livelihoods of rural dwellers. In the present research study an attempt was made to probe out the reasons due to which agricultural services of social organizations play a role in improving agricultural productivity and livelihoods of respondents. The data in this regard is given in Table 6 .

The data tabulated in Table 6 show that in extension education services majority $(43.9 \%)$ of the respondents said that social organizations provided good quality extension and education related services to the rural community. The similar reason 
Table 6. Percentage distribution of the respondents according to their opinion about reasons due to which different agricultural services of non-state actors improve their overall agricultural productivity and livelihood.

\begin{tabular}{lcccccc}
\hline Agricultural Services & \multicolumn{2}{c}{$\begin{array}{c}\text { Good quality } \\
\text { services }\end{array}$} & \multicolumn{2}{c}{ Timely } & \multicolumn{2}{c}{ Competency of } \\
& availability & \multicolumn{2}{c}{ staff } \\
\cline { 2 - 7 } & \multicolumn{1}{c}{ f } & \multicolumn{1}{c}{ F } & \multicolumn{1}{c}{ \% } & \multicolumn{1}{c}{ f } & \% \\
\hline Extension education & 126 & 43.9 & 112 & 39.0 & 49 & 17.1 \\
Trainings related to crops/fruits and vegetable production & 113 & 34.0 & 122 & 36.7 & 97 & 29.2 \\
Trainings related to livestock production and management & 120 & 36.3 & 92 & 28.0 & 116 & 35.4 \\
Poultry management & 136 & 63.0 & 35 & 16.2 & 45 & 20.8 \\
Forestry services & 73 & 48.3 & 54 & 35.8 & 24 & 15.9 \\
Vaccination for livestock & 94 & 54.0 & 48 & 27.6 & 32 & 18.4 \\
Awareness campaigns regarding latest agricultural technologies & 102 & 52.3 & 45 & 23.1 & 48 & 24.6 \\
\hline
\end{tabular}

Table 7. Mean and SD regarding satisfaction of respondents about performance of respective non-state organizations in providing agricultural services.

\begin{tabular}{|c|c|c|c|c|c|c|c|}
\hline \multirow[t]{2}{*}{ Agricultural services } & \multicolumn{2}{|c|}{ Sungi's villages } & \multicolumn{2}{|c|}{ Al-Khidmat's villages } & \multicolumn{2}{|c|}{ RDSO's villages } & \multirow[t]{2}{*}{ F-test } \\
\hline & Mean & SD & Mean & SD & Mean & SD & \\
\hline Extension education & 3.45 & 1.097 & 1.85 & 0.880 & 3.35 & 0.592 & $156.60 * *$ \\
\hline $\begin{array}{l}\text { Trainings related to crops/fruits and } \\
\text { vegetable production }\end{array}$ & 3.13 & 1.079 & 1.73 & 0.711 & 3.16 & 0.990 & $113.10 * *$ \\
\hline $\begin{array}{l}\text { Trainings related to livestock } \\
\text { production and management }\end{array}$ & 3.59 & 0.998 & 1.90 & 0.775 & 3.53 & 0.953 & $164.50 * *$ \\
\hline Poultry management & 3.57 & 1.071 & 2.15 & 1.073 & 3.66 & 1.016 & $96.35^{* *}$ \\
\hline Forestry services & 3.06 & 1.125 & 1.23 & 0.561 & 3.15 & 0.792 & $239.02 * *$ \\
\hline Vaccination for livestock & 3.21 & 1.173 & 1.36 & 0.688 & 3.49 & 0.739 & $251.28 * *$ \\
\hline $\begin{array}{l}\text { Awareness campaigns regarding latest } \\
\text { agricultural technologies }\end{array}$ & 3.43 & 1.089 & 1.70 & 0.758 & 3.19 & 0.757 & $169.30 * *$ \\
\hline Overall Mean & 3.35 & & 1.70 & & 3.36 & & \\
\hline
\end{tabular}

**Highly Significant $(\mathrm{P}<0.05)$

was also pointed out in case of trainings related to livestock production \& management, poultry management services, forestry services, vaccination for livestock and awareness campaigns regarding latest agricultural technologies as reported by $36.3,63.0,48.3,54.0$ and $52.3 \%$, respectively. These results also showed that in case of trainings related to crops/fruits and vegetable production, majority of the respondents (36.7\%) said that in time availability of these trainings imparted by non-state actors (organizations) improved their agricultural productivity as well as their livelihoods.

These results also indicate that in majority of the agricultural related services, competency of the staff of non-state social organizations as major reason behind bringing improvement in agricultural productivity and livelihoods of rural people was not reported by majority of the respondents. This showed that the staff of non-state organizations is not so much competent to deliver agricultural services at the door steps of rural community. They argued that as compared to the state agriculture extension department, the services provided by social organizations to improve the livelihood standards of rural community of study area were of good quality. It was also noted during qualitative individual interviews and focus group discussion meetings that the community of the research area relied more on agricultural information delivered by social organizations working in the area. During discussion some respondents also reported three major reasons (not up to standard, delay in availability, and poor quality) due to which agricultural related services provided by non-state actors (organizations) didn't improve their agricultural productivity and also their livelihoods.

Satisfaction level of respondents about performance of agricultural services provided respective non-state organizations: The respondents were asked question to inquire about their general satisfaction level about the overall performance of non-state organization in providing different agricultural services. The satisfaction level of respondents were measured through five (5) point likert type scale $(1=$ highly dissatisfied, 2 = dissatisfied, $3=$ undecided, $4=$ satisfied, $5=$ highly satisfied). The results in this regard are presented in Table 7.

The data presented in Table 7 depicted that the satisfaction level of respondents was high (overall $\bar{x}=3.36 / 5.00$ ) about performance of RDSO in delivering agricultural services to the rural community than performance of Sungi Development Foundation (overall $\overline{\mathrm{x}}=3.35 / 5.00$ ) and Al-Khidmat 
Foundation (overall $\bar{x}=1.70 / 5.00$ ). This showed that respondents were not satisfied with the performance of AlKhidmat Foundation regarding provision of agricultural services to the rural people. This might be due to the reason of low involvement rate of religious or faith-based organizations like Al-Khidmat Foundation in agriculture related activities. The same was also quoted by Khan (1999) who concluded that religious based organizations showed least interest in delivering agricultural related services to the rural community. Such organizations actively involved in educational and health related activities in developing countries like Pakistan as reported by Rakodi (2007). The result of F-test showed that there is highly significant difference $(\mathrm{P}<0.05)$ in the satisfaction level of respondents of those villages in which all the three non-state organization were working. This showed the diversity of satisfaction level of respondents belonging to different organizations.

Conclusions: From the results it was concluded that majority of the respondents had age between 36-50 years with secondary (10 years of schooling) educational level. The land holding size of the respondents in the study area was found to be very small. The average size of land holding in the study area was 43.65 Kanals. It was concluded that an overwhelming majority of the respondents received agricultural services from non-state institutions/organizations. Further it was also concluded that responses of more than a large majority of the respondents were in favour of the statement that agricultural services of non-state actors improve their overall agricultural productivity and had positive impacts on our livelihoods. Increase crop productivity and enhance food security situation in the research area were the major impacts of agricultural services rendered by non-state organizations. The major reasons behind the success of non-sate efforts were the good quality of their services, in time availability, and competency of staff as reported by majority of the respondents. Finally, it was also concluded that there was highly significant difference between the satisfaction level of the respondents about the performance of state and non-state actors (social organizations) with regard to the delivery of different agriculture related services $(\mathrm{P}<0.05)$ to the farming community.

Acknowledgment: This paper is the part of Ph.D. research of principal author conducted at Institute of Agri. Extension and Rural Development, University of Agriculture, Faisalabad, Pakistan. The authors highly acknowledged the financial support of National Center for Competence in Research (NCCR) North-South, Switzerland and Sustainable Development Policy Institute (SDPI), Islamabad, Pakistan.

\section{REFERENCES}

Ahmad, I., M.S. Nazar, S. Arifullah, M. Akram and N. Farid. 2009. A non-conventional way of getting extension to farmers. Sarhad J. Agric. 25: 623-627.

Ahmad, N., M. Israr, S.N. Shaukat, M.M. Shafi and A. Khan. 2009. Role of village organizations in the execution of Malakand Rural Development Project interventions in Notheran Pakistan. Sarhad J. Agric. 25:657-663.

Ahmed, I., M. Idress, N. Shah and S.W. Shah. 2009. Performance digest of agriculture extension services rendered by public sector and NGOs in district Kohat of NWFP, Pakistan. Sarhad J. Agric. 25:617-621.

Ajieh, P.C., A.E. Agwu and A.C. Anyanwu. 2008. Constraints to privatization and commercialization of agricultural extension services as perceived by extension professionals and farmers. Afr. J. Agric. Res. 3:343-347.

Ali, S., M. Ahmad, T. Ali, S.W. Hassan and M. Luqman. 2011. Role of private extension system in agricultural development through advisory services in the Punjab, Pakistan. Pak. J. Sci. 63:70-73.

Botchwey, N.D. 2006. The Religious sector's presence in local community development. J. Plan. Edu. Res. 27:3648.

Cerdán-Infantes, P., A. Maffioli and D. Ubfal. 2008. The impact of agricultural extension services: The case of grape production in Argentina. Inter-American Development Bank Office of Evaluation and Oversight Working Paper: OVE/WP-05/08. Washington, D.C.

Cervantes-Godoy, D. and J. Dewbre. 2010. Economic importance of agriculture for poverty reduction. OECD Food, Agriculture and Fisheries Papers, No. 23, OECD Publishing.

Chipeta, D. 2006. Demand driven agricultural advisory services. Swiss Center for Agricultural Extension and Rural Development (AGRIDEA), Lindau. Neuchâtel Group.

DFID. 2004. Agriculture, growth and poverty reduction. Available online with updates at www.dfid.gov.uk

FAO. 2003. Agricultural extension, rural development and the food security challenge. Food and Agriculture Organization of the United Nations, Rome, Italy.

FAO. 2012. The State of Food Insecurity in the World 2012: Economic growth is necessary but not sufficient to accelerate reduction of hunger and malnutrition. Rome, FAO.

Farooq, A., M. Ishaq, N.A. Shah and R. Karim. 2010. Agricultural extension agents and challenges for sustainable development: A case study of Peshawar Valley. Sarhad J. Agric. 26:419-426.

Ghaus-Pasha, A. 2004. Role of civil society organizations in the governance. $6^{\text {th }}$ Global Forum on Reinventing Government towards Participatory and Transparent 
Governance; 24-27, May 2005, Seoul, Republic of Korea.

Haque, U.I. 2002. Uplift of landless poor through agricultural reforms: WB. Dawn Econ. Business Rev., 29 April-05 May, 2002; pp.1-6.

Jalal-Ud-Din, M. 2011. The socio-economic problems of small farmers in adopting new agricultural technology: A case study of three villages in district Mardan. Sarhad J. Agric. 27:299-304.

Khan, A. and M. Akram. 2012. Farmers perception of extension methods used by extension personnel for dissemination of new agricultural technologies in Khyber Pakhtunkhwa, Pakistan. Sarhad J. Agric. 28:511-520.

Khan, M.Z., J. Ullah, S. Ahmad and M. Qasim. 2012. Assessing professional capabilities of agriculture officers foe Weed control. A case study of Khyber PakhtunkhwaPakistan. Pak. J. Weed Sci. Res. 18:79-90.

Khan, N. 1999. Assisting severely disadvantaged agricultural areas in Pakistan: The potential for improving the interaction and effectiveness of development partners research, extension and village religious leaders. Community development. Community based learning and outreach. Available online with updates at http://wikieducator.org/images/4/45/Nowshad_Khan.pdf )

Khan, N.A. 2009. Role of private sector in the promotion of education. Conference report on Education in FATA/NWFP (Pakhtunkhwa)- Challenges and opportunities. March 19, 2009; Baacha Khan Trust Educational Foundation (BKTEF), Peshawar, Pakistan.

Luqman, M., B. Shahbaz and T. Ali. 2013. Civil society organizations: nature and their role in rural development: A case study of Hazara region of Pakistan's Khyber Pakhtunkhwa province. Life Sci. 10:91-98.

McCulloch, N., J. Weisbrod and C.P. Timmer. 2007. Pathways out of poverty during an economic crisis: an empirical assessment of rural Indonesia. World Bank Policy Research Working Paper 4173, World Bank, Washington.
Muzari, W., W. Gatsi and S. Muvhunzi. 2012. The impacts of technology adoption on smallholder agricultural productivity in Sub-Saharan Africa: A Review. J. Sust. Dev. 5:69-70.

Naeem, M.R. 2005. Self-perceived role of rural youth in agricultural and rural development in district Faisalabad. M.Sc. (Hons.) Diss., Dept. Agri. Ext., University of Agriculture, Faisalabad, Pakistan.

Nederlof, E.S., B. Wennink and W. Heemskerk. 2010. Access to agricultural services. Background Paper for the IFAD Rural Poverty Report 2010. Royal Tropical Institute, KIT Development Policy \& Practice, Amsterdam.

Pervaiz, U., F. Khan, D. Jan, Zell-e-Huma and M. Zafarullah. 2013. An analysis of sugarcane production with reference to extension services in union council MalakandherPeshawar. Sarhad J. Agric. 29:145-150.

Saliu, J.O., P.C. Obinne and S.I. Audu. 2009. Trends in agricultural extension services in Africa: Options for new approaches. J. Agric. Ext. Rural Dev. 1:71-76.

Shah, N., N. Khan, I.U. Haq and M. Idrees. 2013. Role of grassroots community organizations (GRCO) in poverty alleviation: Evidence from the community empowerment interventions in Haripur district. Sarhad J. Agric. 29:325330.

Siddiqui, S. 2006. Teacher education for sustainable change: practices and possibilities. Paper presented at $9^{\text {th }}$ sustainable development conference, 13-15 December. Sustainable development policy institute (SDPI), Islamabad, Pakistan.

UNDP. 2012. Social audit of local governance and delivery of public services 2011-12: National Report. United Nations Development Programme, Pakistan.

USDA. 2007. Off-farm income, technology adoption, and farm economic performance. Economic research report No. 36. United States Department of Agriculture. Available online with updates at www.ers.usda.gov/media/200316/err36_1_.pdf 